\title{
Konsep Perlindungan Tawanan Perang Menurut Hukum Humaniter Internasional dan Hukum Islam
}

\author{
Hanung Hisbullah Hamda
}

\begin{abstract}
Abstrak
Generally, there is no fundamental contradiction between concept of Intemational Humanitaraian Law and Islamic Law in protecting prisoners of war. But there are still differences in operational field. Both Intemational Humanitaraian Law and Islamic Law protect the rights of prisoners of war in medical support, their human values and their right to get protection guarantee. Both concepts also have a mutual dependence, because some West scholars admitted that treatment concept of prisoners of war in International Humanitarian Law adopted from Islamic concept.
\end{abstract}

\section{Pendahuluan}

Kurang lebih satu dasa warsa yang lalu Samuel P. Hutington dalam tesisnya, Clash of Civilization, telah memprediksikan terjadinya benturan antara dua peradaban besar, kebudayaan Barat dengan Timur. Meskipun tidak sepenuhnya benar, tampaknya tesis tersebut kini terbukti dan benar-benar terjadi. Benturan peradaban antara Barat yang lebih diwakili oleh Amerika Serikat dan Timur yang diwakili oleh Islam telah berkembang kearah konflik bersenjata atau perang terbuka yang melibatkan banyak negara. Seiring dengan perkembangan dunia saat ini, model dan subjek peperangan pun juga banyak mengalami pergeseran. Perang tidak lagi hanya dilakukan oleh pihak-pihak yang berstatus sebagai sebuah entitas negara atau kerajaan tetapi bisa juga oleh sebuah organisasi atau gerakan bawah tanah semacam AI Qaeda, Jamaah Islamiyah, Hamas dan sebagainya yang dalam konteks Amerika disebut sebagai teroris.
Perang terhadap "terorisme" yang dilancarkan oleh Amerika Serikat sebagai akibat peristiwa peledakan gedung WTC telah menghadirkan banyak penderitaan bagi umat manusia. Salah satu pikak yang harus menanggung penderitaan perang adalah para tawanan perang. Dalam praktiknya selama ini tawanan perang kurang mendapatkan perlindungan baik harkat, martabat, maupun keselamatan jiwanya. Contoh konkrit yang bisa dilihat adalah kasus-kasus yang terjadi pada tawanan perang di Irak, Guantanamo, Afganistan dan daerah-daerah konflik lainnya.

Di Irak, Afganistan, dan penjara Guantanamo, para tawanan perang telah mendapatkan perlakuan yang tidak manusiawi dari tentara Amerika Serikat. Penyiksaan, intimidasi, pemukulan, dan sebagainya adalah hal yang harus dihadapi tawanan sehari-hari Menurut sumber dari Al Jazeera.net, kelompok-kelompok perlawanan di lrak juga tidak memberikan 
perlindungan yang semestinya bagi tawanan. Sebuah rekaman video kekejaman berkualitas rendah menampilkan seorang tawanan warga Amerika Serikat yang dipenggal sebagai balasan atas perlakuan tentara Amerika di Abu Ghraib dan Guantanamo. ${ }^{1}$

Fakta kesewenangan terhadap tawanan perang yang terjadi di berbagai belahan dunia saat ini, menarik penulis untuk membahas tentang konsep perlindungan tawanan perang dalam Hukum Humaniter Internasional dan untuk selanjutnya akan dipersandingkan dengan konsep perlindungan tawanan perang dalam Hukum Islam.

\section{Perlindungan Terhadap Tawanan Perang Dalam Perspektif Hukum Humaniter International}

\section{Pengertian Prisoner of War dalam Hukum Humaniter International}

Hukum Humaniter Internasional menentukan bahwa tidak semua orang yang ditawan oleh pihak lawan mempunyai hak untuk diperlakukan sebagai tawanan perang (Prisoners of War). J.G. Starke menjelaskan bahwa dalam suatu konflik bersenjata, pihak-pihak yang bertikai dibagi kedalam dua status yaitu satu kelompok mempunyai status sebagai kombatan dan berhak ikut serta secara langsung dalam permusuhan, boleh membunuh dan dibunuh dan apabila tertangkap diperlakukan sebagai tawanan perang. Sedang kelompok yang lain memiliki status sebagai civilian.yang tidak boleh turut serta dalam permusuhan, harus dilindungi dan tidak boleh dijadikan sasaran serangan. Kombatan sendiri terdiri atas dua golongan yaitu lawful combatant dan unlawful combatant. Lawful combatant akan mendapatkan perlindungan sebagai tawanan perang dan berstatus Prisoner of War karena ia mengindahkan ketentuan Hukum Humaniter Internasional. Sedangkan unlawful combatant mereka akan mendapatkan resiko yang lebih berat atau perlakuan khusus yang lebih keras apabila mereka tertangkap. ${ }^{2}$

Hukum Humaniter Internasional juga menentukan bahwa seseorang yang berstatus sebagai combatant (dalam hal ini lawful combatant) otomatis berhak diperlakukan sebagai Prisoner of War apabila mereka tidak mampu lagi melanjutkan pertempuran dan tertangkap pihak lawan. Tetapi ada pula sekelompok penduduk sipil tertentu, walaupun mereka bukan combatant, apabila jatuh ke tangan musuh berhak pula mendapatkan status Prisoner of War sebagaimana yang diatur Pasal 4A Konvensi Jenewa III tahun $1949 .^{3}$ Pasal ini menyebutkan bahwa mereka yang berhak

' Sandera Warga AS Dipenggal di Irak, Aljazeera.net, edisi Rabu, 12 Mei 2004 diakses tanggal 17 Desember 2004, jam 09.33 dari http://www.google.co.id

${ }^{2}$ J.G. Starke, Introduction to International Law, Tenth Edition, Butterwoth, 1989, hlm. 547

${ }^{3}$ Ketentuan mengenai siapa saja yang dapat diperlakukan sebagai tawanan perang ini dilengkapi kembali dalam Protokol Tambahan I, khususnya Pasal 43 (tentangAngkatan Bersenjata) dan ketentuan lainnya mengenai tentara bayaran dan mata-mata: Ketentuan baru dalam Protokol juga menyatakan bahwa apabila seorang yang ditangkap diragukan statusnya apakah dia kombatan ataukah penduduk sipil, maka ia akan tetap menikmati status sebagai tawanan perang sampai pengadilan yang berkompeten menetapkan status sebenarnya (Pasal 45 Protokol Tambahan I). Lihat juga Arlina Permanasari dkk, Pengantar Hukum Humaniter, ICRC, Jakarta, 1999, hlm. 164 
mendapatkan status sebagai tawanan perang (Prisoner of War) adalah sebagai berikut:4

a. Para anggota angkatan perang dari pihak yang bersengketa, anggota-anggota milisi atau korps sukarela yang merupakan bagian dari angkatan perang itu.

b. Para anggota milisi lainnya, termasuk gerakan perlawanan yang diorganisasikan (organized resistance movement) yang tergolong pada satu pihakyang bersengketa dan beroperasi di dalam atau di luar wilayah mereka, sekalipun wilayah itu diduduki, dan memenuhi syarat-syarat sebagai berikut: 1) dipimpin oleh orang yang bertanggung jawab atas bawahannya; 2) menggunakan tanda pengenal tetap yang dapat dilihat dari jauh; 3) membawa senjata secara terbuka; 4) melakukan operasinya sesuai dengan hukum dan kebiasaan perang.

c. Para anggota angkatan perang reguler yang menyatakan kesetiaannya pada suatu pemerintah atau kekuasaan yang tidak diakui oleh negara penahan.

d. Orang-orang yang menyertai angkatan perang tanpa dengan sebenarnya menjadi anggota dari angkatan perang itu, seperti anggota sipil awak pesawat terbang militer, wartawan perang, anggotaanggota kesatuan angkatan kerja, dinasdinas yang bertanggung jawab atas kesejahteraan angkatan perang, asalkan mereka telah mendapatkan pengakuan dari angkatan perang yang disertainya dan melengkapi diri mereka dengan sebuah kartu pengenal. e. Awak kapal niaga termasuk nahkoda, pandu Jaut, taruna serta awak pesawat terbang sipil dari pihak-pihak yang bersengketa yang tidak mendapat perlakuan yang lebih baik menurut ketentuan-ketentuan apapun dalam hukum internasional.

f. Penduduk wilayah yang belum diduduki, yang ketika musuh mendekat, atas kemauannya sendiri dan dengan serentak mengangkat senjata untuk melawan pasukan-pasukan yang datang menyerbu, tanpa memiliki waktu yang cukup untuk membentuk kesatuan-kesatuan bersenjata secara teratur, asal saja mereka membawa senjata secara terbuka dan menghormati hukum dan kebiasaan perang.

Dari enam golongan tersebut di atas, poin $a, b, c$, dan $f$ termasuk dalam kategori kombatan, yang apabila tertangkap akan diperlakukan sebagai tawanan perang. Sedangkan poin $d$ dan e berada dalam kategori penduduk sipil, namun apabila mereka ditangkap oleh pihak musuh tetap berhak mendapatkan status sebagai Prisoner of War. ${ }^{5}$

Ketentuan tentang siapa yang berhak mendapatkan status dan perlakuan sebagai Prisoners of War ini kemudian disempurnakan dalam Protokol 1 tahun 1977 yang memberikan definisi baru dari apa yang disebut sebagai Angkatan Bersenjata dan kombatan. Pasal 43 memberi batasan dari Angkatan Bersenjata sebagai berikut: 6

1. Angkatan Bersenjata dari pihak yang bertikai terdiri dari Angkatan Bersenjata yang terorganisir (organized armed forces),

${ }^{4}$ Lihat Pasal 4 AGeneva Convention (III) Relative to the Treatment of Prisoners of War; August 12, 1949

${ }^{5}$ Frits. Kalshoven, Constraint of The Waging of War, Second Edition, ICRC, Genewa, 1987, hlm. 41.

${ }^{6}$ Haryomataram, 1984. Hukum Humaniter. Jakarta: Rajawali. HIm. 72-75. 
group dan unit yang berada di bawah komando yang bertanggung jawab atas kelakuan anak buahnya kepada pihak tersebut, sekalipun pihak itu diwakili oleh pemerintah atau penguasa (authority) yang tidak diakui oleh pihak lawan (adverse party). Angkatan Bersenjata tersebut harus tunduk kepada sistem disiplin kesatuan (internal diciplinary system ) yang antara lain berisi pelaksanaan ketentuan hukum internasional yang berlaku dalam pertikaian bersenjata.

2. Anggota Angkatan Bersenjata dari pihak yang bertikai (kecuali personal medik dan pendeta seperti tersebut dalam Pasal 37 konvensi Jenewa III adalah Combatan, yaitu mereka berhak untuk turut serta secara langsung dalam permusuhan.

3. Apabila salah satu pihak yang bertikai memasukkan sebuah kesatuan (agency) para militer atau penegak hukum dalam Angkatan Bersenjata mereka, maka mereka wajib memberitahukan hal ini pada pihak-pihak lain yang bertikai.

Kemudian di dalam Pasal 44 diatur tentang kombatan dan tawanan perang dengan ketentuan-ketentuan sebagai berikut:?

1. Setiap kombatan, seperti ditentukan dalam Pasal 43, yang jatuh dalam kekuasaan pihak lawan, akan menjadi tawanan perang (Prisoner of War)

2. Sekalipun semua kombatan harus mentaati ketentuan-ketentuan Hukum internasional yang berlaku dalam pertikaian bersenjata, namun pelanggaran ketentuan tersebut tidak akan menghilangkan haknya untuk menjadi kombatan apabila ia jatuh dalam kekuasaan pihak lawan, dan juga tidak menghilangkan haknya menjadi tawanan perang, kecuali apa yang ditentukan dalam ayat 3-4.

3. Untuk menambah perlindungan bagi penduduk sipil dari akibat permusuhan, kombatan diharuskan untuk membedakan diri dari penduduk sipil pada waktu mereka sedang menyerang atau di dalam suatu operasi militer yang mendahului serangan tersebut. Tetapi mengingat dalam suatu pertikaian bersenjata terdapat situasi dimana, mengingat sifat permusuhan tersebut, jika kombatan tidak dapat membedakan diri, ia akan tetap memperoleh statusnya sebagai kombatan asal dalam keadaan tersebut ia membawa senjata secara terbuka: a) Selama setiap pertempuran (engagement) militer; b) Selama ia dapat dilihat kelihatan oleh musuh pada waktu ia terlibat dalam suatu persiapan (deployment) militer mendahului serangan dimana ia turut serta. Perbuatan yang memenuhi ketentuan ini tidak boleh dianggap sebagai licik (perfidious) dalam Pasal 37 ayat $1 c$.

4. Seorang kombatan yang jatuh dalam kekuasaan pihak lawan sedang ia tidak memenuhi persyaratan yang ditentukan dalam kalimat kedua dari Pasal 3, akan kehilangan haknya sebagai tawanan perang, tetapi ia akan diberikan perlindungan yang sama dalam segala aspek seperti yang diberikan pada tawanan perang oleh konvensi jenewa III dan protokol ini.

5. Setiap kombatan yang jatuh ke dalam kekuasaan pihak lawan, pada waktu (sedang) tidak terlibat dalam serangan atau dalam suatu operasi militer sebagai persiapan suatu serangan, tidak akàn 
kehilangan haknya (forfeit). Sebagai kombatan dan tawanan perang sebagai akibat kegiatannya sebelumnya.

6. Pasal ini tidak mengurangi (without prejudice) hak setiap orang untuk menjadi tawanan perang sesuai dengan pasal 4 Konvensi Jenewa III.

7. Pasal ini tidak dimaksudkan untuk mengubah kebiasaan secara umum telah diterima negara-negara yang berhubungan dengan pemakaian seragam (uniform) oleh kombatan yang termasuk kesatuan yang reguler dan berseragam serta bersenjata (regular uniformed armed units) dari pihak yang bertikai.

8. Sebagai Tambahan dari kategori orang tersebut dalam pasal 13 Konvensi Jenewa III, maka semua anggota Angkatan Bersenjata dari pihak bertikai seperti dirumuskan dalam pasal 43 protokol ini, berhak atas perlindungan yang diatur dalam konvensi tersebut, apabila mereka terluka atau sakit, baik di darat maupun di laut.

Definisi Angkatan Bersenjata dan kombatan yang dirumuskan dalam protokol ini (sangat) berbeda dengan apa yang telah ditentukan dalam konvensi-konvensi sebelumnya. Perlu juga dicatat bahwa baru dalam protokol ini dinyatakan secara tegas bahwa kombatan adalah mereka yang berhak untuk ikut serta secara aktif atau langsung dalam permusuhan.

Pasal 43 ayat $1 \mathrm{di}$ atas menghilangkan diskriminasi antara regular armies dengan kelompok bersenjata (armed group) yang lain. Dengan diterimanya Pasal 43 dan 44 Protokol
I tahun 1977 maka penduduk sipil yang ikut terlibat langsung dalam permusuhan dimasukkan kedalam kategori kombatan. Konsekuensinya kalau mereka jatuh dalam kekuasaan pihak lawan harus diperlakukan sebagai tawanan perang (berstatus sebagai Prisoner of War).

\section{Prinsip dan Ketentuan Tentang Perlakuan Terhadap Tawanan Perang dalam Konvensi Jenewa III Tahun 1949}

Pengaturan terhadap tawanan perang (Prisoners of War) dalam Hukum Humaniter Internasional secara rinci terdapat di dalam Konvensi Jenewa III tahun 1949 (Geneva Convention (III) Relative to the Treatment of Prisoners of War) dan Protokol Tambahan I tahun 1977 (Protocol Additional to the Geneva Conventions of 12 August 1949, and relating to the Protection of Victims of International Armed Conflicts). Berdasarkan beberapa literatur tentang Hukum Humaniter Internasional, prinsip-prinsip perlakuan terhadap tawanan perang yang ada dalam Konvensi Jenewa III tahun 1949 memuat hal-hal sebagai berikut: ${ }^{8}$

1. Jaminan penghormatan; artinya para tawanan perang harus diperlakukan secara manusiawi;

2. Jaminan perlindungan; artinya mereka harus dilindungi dari ketidakadilan dan bahaya yang mungkin timbul dari suatu peperangan, dan terhadap kemungkinan atas perkosaan integritas kepribadian mereka. Harus ada tindakan-tindakan yang perlu untuk menjamin hal ini;

3. Jaminan kesehatan; artinya mereka berhak atas perawatan kesehatan yang setara dan

${ }^{8}$ Hans Peter Gasser, International Humanitarian Law, An Introduction, Separate Print from Hans Haug, Humanity for All, ICRC and Red Crescen Movemen, Henry Dunant Institute, Paul Haupt Publisher, Berne Stuttgart, Vienna, 1993, hlm 29-30 
tidak boleh diabaikan, walaupun ia pihak musuh.

Berdasarkan ketentuan-ketentuan dalam Konvensi Jenewa III tahun 1949 (Geneva Convention (III) Relative to the Treatment of Prisoners of War) dapat diringkas bahwa perlakuan yang harus diberikan kepada tawanan perang adalah sebagai berikut: 9

1. Pada waktu tertangkap, para tawanan tidak boleh dipaksa memberikan keterangan kecuali mengenai identitas mereka. Penyiksaan dan perlakuan kejam terhadap mereka dipandang sebagai kejahatan perang.

2. Segera setelah tertangkap tawanan perang berhak dilengkapi dengan kartu penagkapan. Kartu penangkapan ini selanjutnya dikirim ke Biro Penerangan Resmi di negara asal tawanan perang melalui Badan Pusat Pencarian ICRC (ICRC Central Tracing Agency). Badan Pusat Pencarian ini memiliki tugas memberikan keterangan kepada keluarga para tawanan. Dengan cara ini maka hubungan tawanan dengan keluarga mereka dapat tetap terjalin.

3. Secepatnya, para tawanan perang harus dipindahkan dari kawasan berbahaya ke tempat yang aman. Kondisi kehidupan mereka harus setara dengan kondisi kehidupan dari anggota angkatan perang negara penawan.

4. Sedapat mungkin kondisi penawanan mempertimbangkan adat dan kebiasaan yang dilakukan para tawanan.

5. Para tawanan yang sehat dapat diminta untuk bekerja, ${ }^{10}$ tetapi mereka dapat melakukan pekerjaan-pekerjaan berbahaya apabila mereka menyetujuinya.

6. Tawanan perang berhak melakukan korespondensi dengan keluarga yang dikirim melalui ICRC.

7. Tawanan perang tunduk pada hukum negara penahan, khususnya yang berlaku pada Agkatan Bersenjata. Jika terjadi pelanggaran, mereka dapat dijatuhi sanksi pidana sesuai dengan hukum negara penawan, termasuk terhadap kejahatan yang dilakukan sebelum mereka ditawan.

8. Tawanan perang yang dihukum berhak mendapatkan jaminan peradilan yang wajar dan bila terbukti bersalah dan dijatuhi hukuman, maka ia tetap berstatus sebagai tawanan perang. Artinya ia berhak untuk dipulangkan kembali kenegara asalnya .

9. Dilarang melakukan tindakan pembalasan (reprisal) terhadap tawanan perang.

Rina Rusman menjelaskan bahwa dalam hal perlindungan terhadap tawanan perang, Konvensi Jenewa III tahun 1949 (Geneva Convention (III) Relative to the Treatment of Prisoners of War) memuat ketentuan-ketentuan umum sebagai berikut:"1"

1. Tawanan perang pada dasarnya berada dalam kekuasaan penguasa musuh (negara), bukan dalam kekuasaan perorangan atau

${ }^{9}$ Arlina Permanasari, dkk., Hukum Humaniter, ICRC, Jakarta, 1999, hlm166-168

${ }^{10}$ Berdasarkan Pasal 62 Konvensi Jenewa III, tawanan perang yang dipekerjakan berhak untuk mendapatkan upah yang pantas. Besarnya ditentukan oleh penguasa, tetapi tidak boleh kurang dari $1 / 4$ franc Swiss untuk satu hari kerja penuh.

"Rina Rusman, Beberapa Perkembangan Hukum Humaniter Internasional, Makalah disampaikan dalam Kursus Dasar HHI dan HAM untuk Dosen Perguruan Tinggi Negeri dan Swasta yang diselenggarakan di Banjarmasin atas kerja sama antara Fakultas Syari'ah IAIN Antasari dan ICRC Delegasi Jakarta, 2004, hlm. 15 
satuan yang menawan;

2. Terlepas dari tanggung jawab perorangan yang mungkin ada, pada dasarnya penguasa (negara) sebagai pihak yang bertangung jawab atas perlakuan terhadap tawanan perang: 12

3. Tawanan perang harus diperlakukan secara manusiawi; ${ }^{13}$

Adapun ketentuan-ketentuan khusus yang harus diterapkan terhadap tawanan perang menurut Konvensi Jenewa III tahun 1949 memuat hal-hal sebagai berikut: ${ }^{14}$

a. Tawanan perang tidak boleh dijadikan objek mutilasi, eksperimen pengobatan atau jenis percobaan ilmiah apapun.

b. Kapanpun mereka harus dilindungi dari tindakan-tindakan kekerasan atau intimidasi, penghinaan dan menjadi tontonan umum.

c. Tindakan balas dendam (reprisal) terhadap tawanan perang dalam bentuk apapun dilarang. ${ }^{15}$

d. Harus mempertimbangkan pangkat, jenis kelamin, keadaan kesehatan, umur, dan kualifikasi keahlian.

e. Seluruh tawanan perang harus diperlakukan sama tanpa memandang perbedaan berdasarkan ras, kebangsaan, agama, orientasi politik, ataupun kriteria lainnya yang sejenis. ${ }^{16}$ f. Setiap tindakan yang melawan hukum atau kelalaian negara penawan yang berakibat pada kematian atau benarbenar membahayakan kesehatan para tawanan perang adalah dilarang dan dianggap sebagai pelanggaran berat terhadap konvensi.

\section{Ketentuan Tentang Perlakuan Terhadap Tawanan Perang dalam Protokol Tambahan I tahun 1977}

Protokol Tambahan I tahun 1977 (Protocol Additional to the Geneva Conventions of 12 August 1949, and relating to the Protection of Victims of International Armed Conflicts) terdiri dari 120 pasal dan pada dasarnya bertujuan untuk meningkatkan perlindungan bagi penduduk sipil dalam konflik bersenjata internasional. Beberapa ketentuan pokok dalam Protokol Tambahan I antara lain memuat halhal sebagai berikut: ${ }^{17}$

1. Melarang serangan yang membabi buta dan reprisal terhadap penduduk sipil dan obyek-obyek sipil, obyek-obyek yang sangat vital bagi kelangsungan penduduk sipil, benda-benda cagar budaya dan tempattempat religius, bangunan dan instalasi berbahaya, serta lingkungan alam.

2. Memperluas perlindungan yang sebelumnya

${ }^{12}$ Lihat Pasal 12 Konvensi Jenewa III tahun 1949 (Geneva Convention (III) Relative to the Treatment of Prisoners of War)

${ }^{13}$ Lihat Pasal 13 Konvensi Jenewa III tahun 1949 (Geneva Convention (III) Relative to the Treatment of Prisoners of War)

${ }^{14}$ Rina Rusman, Op. Cit., hlm 16

${ }^{15}$ Lihat Pasal 13 Konvensi Jenewa Ill tahun 1949 (Geneva Convention (III) Relative to the Treatment of Prisoners of War)

${ }^{16}$ Lihat pasal 16 Konvensi Jenewa III tahun 1949 (Geneva Convention (III) Relative to the Treatment of Prisoners of War)

${ }^{17}$ ICRC, Advisory Service on International Humanitarian Law, "Protocol Additional to The Genewa Conventions of 1949 for the Protection of War Victims" dalam Arlina Permanasari dkk, Op. Cit., hlm. 129-130 
telah diatur dalam Konvensi Jenewa kepada semua personel medis, unit-unit dan alatalat transportasi medis; baik yang berasal dari organisasi sipil maupun militer.

3. Menentukan kewajiban bagi pihak yang bertikai untuk mencari orang-orang yang hilang (missing persons).

4. Menegaskan ketentuan-ketentuan mengenai suplai bantuan (relief supplies) yang ditujukan pada penduduk sipil.

5. Memberikan perlindungan terhadap kegiatan-kegiatan organisasi pertahanan sipil

6. Mengkhususkan adanya tindakan-tindakan yang harus diambil oleh negara-negara untuk memfasilitasi implementasi hukum humaniter.

Dari keenam pokok ketentuan yang ada dalam Protokol Tambahan I tahun 1977 di atas tampak bahwa yang menjadi pokok bahasan adalah perlindungan terhadap penduduk sipil. Namun meskipun begitu, dalam Protokol Tambahan I tahun 1977 ini juga dimuat beberapa pasal sebagai ketentuan tambahan bagi perlindungan terhadap tawanan perang yang telah diatur dalam Konvensi Jenewa.

Ketentuan tentang tawanan perang yang ada dalam Protokol ini secara garis besar tercakup dalam dua ketentuan pokok. Pertama, ketentuan tambahan tentang siapa yang berhak mendapatkan status sebagai Prisoner of War. Kedua, ketentuan tambahan tentang jaminan kesehatan dan larangan melakukan percobaan-percobaan kesehatan serta larangan penerapan percobaan IImiah dan biologis terhadap tawanan.

Ketentuan tambahan tentang siapa yang berhak mendapatkan status sebagai Prisoner of War terdapat dalam Pasal 43, 44, dàn 45. Pasal 43 menjelaskan tentang definisi Angkatan Bersenjata yang kemudian berhak atas status Prisoner of War. Sedangkan Pasal 44 menjelaskan hak-hak combatant yang intinya sebagai berikut: ${ }^{18}$

1. Setiap kombatan berhak atas status tawanan perang (Prisoner of War)

2. Kombatan yang tidak dapat membedakan diri tetap memperoleh status sebagai kombatan dan Prisoner of War asal dalam keadaan tersebut ia membawa senjata secara terbuka selama setiap pertempuran (engagement) militer dan selama ia dapat dilihat oleh musuh pada waktu ia terlibat dalam suatu persiapan (deployment) militer mendahului serangan dimana ia turut serta.

3. Setiap kombatan yang jatuh ke dalam kekuasaan pihak lawan, pada waktu (sedang) tidak terlibat dalam serangan atau dalam suatu operasi militer sebagai persiapan suatu serangan, tidak akan kehilang-an haknya (forfeit) sebagai kombatan dan tawanan perang sebagai akibat kegiatannya sebelumnya.

Kemudian Pasal 45 pada intinya menyatakan bahwa apabila seorang yang ditangkap diragukan statusnya apakah dia kombatan atau penduduk sipil, maka ia akan tetap menikmati status sebagai tawanan perang sampai pengadilan yang berkompeten menetapkan status sebenarnya. ${ }^{19} \mathrm{Adapun}$ ketentuan tambahan tentang jaminan kesehatan dan larangan melakukan percobaan-percobaan kesehatan serta larangan penerapan percobaan ilmiah dan biologis terhadap tawanan terangkum dalam

${ }^{18}$ Lihat Pasal 44 (Protocol Additional to the Geneva Conventions of 12 August 1949, and relating to the Protection of Victims of internationalArmed Conflicts)

${ }^{19}$ Arlina Permanasari, Op. Cit., hlm. 164 
Pasal 11 Protokol Tambahan I tahun 1977 (Protocol Additional to the Geneva Conventions of 12August 1949, and relating to the Protection of Victims of International Armed Conflicts).

\section{Perlindungan Terhadap Tawanan Perang dalam Hukum Islam}

\section{Pengertian Tawanan Perang dalam Perspektif Hukum Islam}

Secara bahasa (lughawy), tawanan perang dalam bahasa arab disebut sebagai al asiru atau usro al harb. Sedangkan secara terminologi (ishtilahy), tawanan perang atau usro al harb adalah orang-orang kafir yang berperang dan tertangkap dan ditawan hiduphidup oleh pihak pasukan Islam setelah perang berakhir. ${ }^{20}$ Menawan musuh dalam perang di dalam Al Qur'an halai dan dibolehkan dengan dalil surat At Taubah ayat 5 dan surat Muhammad ayat 4.

Farhad Malekian dalam The Concept of Islamic International Criminal Law; A Comparative Study mendefinisikan tawanan perang sebagai berikut:21

Prisoners of War are those have been captured by one means or another during a state of hostility in actual armed conflicts between the conflicting parties and are consequently considered enemy combatants.

Al Ghunaimi dalam bukunya, The Muslim Conception of Internasional Law and Western Approach, mendefinisikan tawanan perang sebagai "The Prisoners of War are the enemy combatants who, in a legitimater war declarateb by a muslim sovereign, were made prisoners by muslim."2z Jika kita teliti kedua pengertian tawanan perang dalam Islam menurut Malekian dan Al Ghunaimi tersebut tampak bahwa yang bisa mejadi tawanan perang dalam Hukum islam adalah kombatan saja. Tetapi sebenarnya kedua pendapat tersebut kurang begitu tepat karena dalam Islam tidak mengenal pembagian orang-orang yang tertawan ke dalam combatant dan non-combatant.

Orang-orang yang tertangkap dan ditahan oleh pihak musuh dalam kajian Islam dibagi ke dalam dua golongan. Pertama, wanita, anakanak, dan yang dihukumi seperti keduanya seperti orang gila, dungu, dan semacamnya. Kedua, golongan laki-laki dewasa yang ikut serta dalam peperangan. Kedua golongan ini dalam Islam akan mendapatkan perlakuan yang berbeda jika mereka tertangkap dan ditahan oleh pihak muslim. Adapun bentuk perlakuan dan ketentuan yang diterapkan terhadap mereka akan dijelaskan kemudian dalam sub pembahasan tentang rumusan ijtihad para fuqaha' mengenai perlakuan terhadap tawanan perang.

\section{Prinsip-prinsip dan Ketentuan Tentang Perlakuan Terhadap Tawanan Perang dalam Al Qur'an dan As Sunnah}

Dalam berbagai literatur Islam, permasalahan tentang tawanan perang bukanlah menjadi sesuatu yang asing lagi. Al Qur'an sebagai pedoman hidup umat Islam memerintahkan apabila orang-orang musyrik sedang memerangi Islam maka umat Islam diperintahkan memerangi dan menangkapi (menawan) mereka dimana saja mereka dijumpai. Mereka

${ }^{20}$ Abdul Baqiy, Sabiluna Al Jihadu, (Mu'asasatu Ar Risalah, Beirut, 1990), hlm. 212

${ }^{21}$ Farah Malekian, The Concept of Islamic International Criminal Law, A Comparative Study, (Kluwer Academic Publishers Group, Lodon, 1994), hlm. 156.

$22 \mathrm{Jbid}$ 
boleh diberi kebebasan jika mereka bertobat, mendir-ikan shalat, dan membayar zakat. ${ }^{23}$

Ada sejumlah prinsip di dalam Al Qur'an dan As Sunnah yang memberikan landasan konseptual bagi perlakuan terhadap tawanan perang, yaitu:

1. Larangan untuk menawan musuh dengan tujuan untuk mendapatkan tebusan sebanyak-banyaknya ketika perang sedang berlangsung dan musuh belum benarbenar dilumpuhkan, sebab tindakan yang paling tepat dilakukan pada saat itu adalah membunuhnya demi keamanan. Dalam surat Al Anfal ayat 67 Allah berfirman: ${ }^{24}$ Artinya: "Tidak patut, bagi seorang nabi mempunyai tawanan sebelum ia dapat melumpuhkan musuhnya di muka bumi. Kamu menghendaki harta benda duniawiyah, sedangkan Allah menghendaki (pahala) akhirat (untukmu). Dan Allah Maha Perkasa lagi Maha Bijaksana."

2. Perintah untuk berdakwah kepada tawanan perang. Allah berfiman dalam surat Al Anfal ayat $70: 25$

Artinya: "Hai...nabi, katakanlah kepada tawanan-tawanan yang ada di tanganmu: "Jika Allah mengetahui ada kebaikan dalam hatimu, niscaya Dia akan memberikan kepadamu yan lebih baik dari apa yang telah diambil dari padamu dan Dia akan mengampuni kamu. Dan Allah Maha Pengampun lagi Maha Penyayang."

Ayat ini menerangkan bahwa kaum muslim mempunyai kewajiban untuk menda'wahkan Islam kepada para tawanan perang

${ }^{23}$ Lihat QS. At Taubah (9): 5

${ }^{24}$ Lihat QS. AlAnfal (8) : 67

${ }^{25}$ Lihat QS. AlAnfal (8): 70

${ }^{26}$ Lihat QS. AlAnfal (8): 71

${ }^{27}$ Lihat QS. Al Baqarah (2): 190 yang berhasil ditangkap tentara Islam. Dalam implementasinya, seorang muslim dilarang memaksakan kepada siapapun termasuk tawanan perang untuk masuk Islam, sebab Allah sendiri menegaskan tidak adanya paksaan dalam beragama.

3. Keharusan mengawasi dan tetap waspada terhadap tawanan. Allah bertirman dalam surat AlAnfal ayat 71:26

Artinya: "Akan tetapi jika mereka (tawanantawanan itu) bermaksud hendak berkhianat kepadamu, maka sesungguhnya mereka telah berkhianat kepada Allah sebelum ini, lalu Allah menjadikan (mu) berkuasa terhadap mereka. Dan Allah Maha Mengetahui Lagi Maha Bijaksana."

4. Larangan bertindak yang melampaui batas terhadap tawanan. Allah berfirman dalam surat Al Baqarah ayat 190:27

Artinya: "Dan perangilah di jalan Allah orang-orang yang memerangi kamu, (tetapi) janganlah kamu melampaui batas, karena sesungguhnya Allah tidak menyukai orangorang yang melampaui batas."

Ayat ini mengandung maksud bahwa meskipun dalam kondisi perang, umat Islam tidak boleh memperlakukan musuh dan tawanan dengan tidak manusiawi. Penyiksaan maupun pelanggaran terhadap kehormatan sangat tidak sejalan dengan jiwa ayat ini. Menurut Imam Ibnu Katsir, yang dimaksud dengan "melampaui batas" dalam ayat ini adalah melakukan hal-hal yang dilarang, seperti memotong-motong mayat, menjarah, membunuh wanita dan 
anak-anak yang tertangkap, menganiaya dan membunuh orang-orang tua, serta menyiksa mereka. ${ }^{28}$

5. Umat Islam harus memberikan perlakuan baik terhadap tawanan dan kepada mereka pada prinsipnya tidak boleh dijadikan budak. Al Qur'an menegaskan bahwa tindakan terhadap tawanan perang pada prinsipnya hanya dua, yaitu dibebaskan dengan baik atau dilepaskan dengan tebusan. Allah berirman dalam surat Muhammad ayat $04::^{29}$ Artinya: "Apabila kamu bertemu dengan orang-orang kafir (di medan perang) maka pancunglah batang leher mereka. Sehingga apabila kamu telah mengalahkan mereka maka tawanlah mereka dan sesudah itu kamu boleh membebaskan mereka atau menerima tebusan sampai perang berhenti. Demikianlah, apabila Allah menghendaki niscaya Allah akan membinasakan mereka tetapi Allah hendak menguji sebagian kamu dengan sebagian yang lain. Dan orang-orang yang gugur pada jalan Allah, Allah tidak akan menyia-nyiakan amal mereka."

6. Islam mewajibkan umatnya memperlakukan tawanan perang dengan baik dan melarang tindakan balas dendam. Sebuah hadits yang di nukil oleh Muhammad Abu Zahroh menerangkan bahwa Nabi saw bersabda: "Kamu terimalah wasiatku supaya berbuat baik kepada para tawanan". ${ }^{30}$ Hadits ini sejalan dengan firman Allah yang artinya: ${ }^{31}$ "Dan mereka memberikan makanan yang disukainya kepada orang miskin, anak yatim, dan orang-orang yang ditawan. Sesungguhnya kami memberikan makanan kepada kamu hanyalah untuk mengharap keridloan Allah, kami tidak menghendaki balasan dari kamu dan tidak pula (ucapan) terima kasih."

Berdasarkan uraian di atas maka dapat disimpulkan bahwa, pengaturan tawanan perang menurut Al Qur'an dan As Sunnah memuat ketentuan-ketentuan sebagai berikut:

a. Larangan menawan dengan tujuan mencari kekayaan dunia semata, bukan karena motif jhad.

b. Jaminan kehormatan, dan perlakuan yang manusiawi (tidak melampaui batas) terhadap tawanan perang. Termasuk di dalamnya jaminan kesehatan jika tawanan tersebut terluka atau sakit.

c. Perintah berda'wah kepada tawanan perang, sebab inti dari jihad suci adalah

${ }^{28}$ Sayyid Quthub, Fi Zhilaalil Qur'an; Tafsir di Bawah Naungan Al Qur'an, Juz Kedua, Bina Ilmu, Jakarta, hlm. 160 Lihat juga Tafsir Ibnu Katsir Juz Il, hIm. 101

${ }^{29}$ Lihat QS. Muhammad (47): 4

${ }^{30}$ M. Abu Zahroh, Al 'Alaaqatu ad Dauliyah, Alih Bahasa Muhammad Zein Hasan Lc. Lt., (Bulan Bintang, Jakarta, 1973), hlm. 149

${ }^{31}$ Lihat Q.S. Al Insaan (76): 8-9

Lihat ketentuan-ketentuan khusus berkaitan dengan tawanan menurut Hamidullah dalam bukunya, The Muslim Conception of Internasional Law and Western Approach, dalam Farah Malekian, The Concept of Islamic Interbational Criminal Law; A Comparative Study, Kluwer Academic Publishers Group, Lodon, 1994, $\mathrm{hlm}$. 158. Lihat juga prinsip-prinsip perang menurut Prof. Dr. MarcelA. Boisard dalam bukunya, L'Himanisme De L'isiam sebagaimana dikutip oleh L. Amin Widodo dalam Figih Siasah dalam Hubungan Internasional, cet. Pertama, Tiara Wacana, Yogyakarta, 1994, hlm. 70 Lihat juga Altaf Gauhar, Tantangan Islam, Alih Bahasa: Anas Mahyudin, (Bandung, PUSTAKA, Perpustakaan Salman ITB), 1982, hlm. 230 Lihat juga dalam Majid Khadduri, The Law of War and Peace in Islam. Baltimore, Maryland, London: The Johns Hopkins University Press, 1941 
menegakkan agama Allah.

Berdasarkan prinsip-prinsip umum dalam Al Qur'an dan As Sunnah di atas, dapat dirumuskan beberapa ketentuan khusus tentang tawanan perang secara terperinci sebagai berikut: ${ }^{32}$

1. Tawanan perang tidak bisa dimintai pertanggungjawaban atas kehancuran dan kerusakan yang terjadi akibat perang.

2. Tawanan perang harus mendapatkan makanan dan kebutuhan primer lainnya, seperti pakaian dan obat-obatan.

3. Pihak penawan harus menyediakan tempat yang aman dan manusiawi bagi para tawanan agar mereka terlindungi.

4. Kehormatan dan martabat tawanan perang harus di jaga dan dihormati oleh pihak penawan.

5. Segala bentuk penyiksaan baik fisik maupun psikhis adalah terlarang badi tawanan perang.

6. Adat istiadat dan kebiasaan para tawanan perang harus mendapatkan perhatian dan dihormati.

7. Perempuan harus mendapatkan penghormatan dan perlindungan lebih karena statusnya.

8. Tidak ada seorangpun yang boleh diperkosa dan dilecehkan secara asusila.

9. Perempuan, anak-anak, orang dungu, dam yang dipersamakan dengan mereka harus mendapatkan penghormatan dan perlakuan khusus mengingat statusnya.

10. Ibu-ibu yang tertawan tidak boleh dipisahkan dari anak-anaknya selama penahanan.

11. Dalam segala kondisi dan situasi, tawanan perang harus diperlakukan secara fair oleh pihak-pihak yang bertikai.
12. Tawanan perang yang sakit, terluka, atau mengalami shok harus mendapatkan perawatan dan pengobatan sebaik dan setara dengan yang diberikan kepada anggota pihak penawan.

13. Komunikasi dengan surat atau bentuk lain harus dijamin oleh pihak penahan.

14. Tawaan perang tidak boleh dipekerjakan terlalu berat.

15. Tawanan perang tidak boleh dipaksa mengangkat senjata untuk membantu pihak penawan.

16. Tawanan perang yang berhasil melarikan diri dan kemudian tertangkap lagi tidak bisa dihukum karena pelarian yang telah ia lakukan. Dia hanya boleh dihukum apabila terbukti telah melakukan tindakan kriminal.

17. Tawanan perang yang melanggar kedisiplinan dapat dihukum dengan sewajarnya.

\section{Rumusan ljtihad Para Fuqaha' Tentang Perlakuan Terhadap Tawanan Perang}

Al Qur'an merupakan sumber hukum pertama dan utama. Di dalamnya me-ngandung ayat-ayat yang berkaitan dengan aqidah (teologi), syari'ah (hukum), dan akhlak (etika). Ayat AI Quran tentang hukum, terkadang ada yang masih bersifat umum dan ada yang sudah terinci. Untuk memahami dan memformulasi produk hukum (istinbath) ayat-ayat ahkam yang masih umum itu diperlukan beberapa perangkat, baik tafsir, hadits, maupun kaidah-kaidah ushul figh. Fuqaha' lah yang dalam konteks ini mempunyai integritas dan otoritas untuk melakukan pembacaan, penafsiran, dan perumusan terhadap ayat-ayat ahkam dalam Al Quran yang masih bersifat general. ${ }^{33}$ Dengan demikian

${ }^{32}$ M. Abu Zahroh, Op Cit, hlm. 15

${ }^{33}$ Abu Bakar Jabir Al Jaziriy, Ensiklopedi Muslim Minhajul Muslim, Darul Kafah, Jakarta, 2003, hlm. 490-491 
dalam tulisan ini perlu dikaji pula tentang hadits-hadits dan pendapat para fuqaha yang berbicara tentang perlakuan terhadap tawanan perang.

Tawanan perang dalam kajian Islam dibagi ke dalam dua golongan. Pertama, Wanita, anakanak, dan yang dihukumi seperti keduanya yaitu orang gila, dungu, dan semacamnya. Bagi golongan ini, rasulullah mengharamkan umat Islam membunuhnya. Penganiayaan fisik, intimidasi dan kekerasan dalam bentuk lain juga dilarang dilakukan terhadap mereka. ${ }^{34}$

Kedua, golongan laki-laki dewasa. Para fuqaha berbeda pendapat tentang bagaimana memperlakukan mereka, apakah harus dibunuh atau di tawan. Terhadap golongan ini, Al Jaziriy menjelaskan bahwa para ulama membolehkan mereka untuk dibunuh, ditawan seterusnya, dibebaskan, ataupun dijadikan budak. Hal ini tergantung pada situasi dan kondisi yang ada. ${ }^{35}$

- Sulaiman Rasjid dalam Fiqih Islam juga menjelaskan bahwa tawanan perang secara teoritis terbagi menjadi dua macam. Pertama, tawanan perempuan dan anak-anak. Mereka tidak boleh dihukum berat (mati) berdasarkan larangan nabi. Sebaiknya mereka ditukar dengan tawanan musuh, dilepaskan, atau dijadikan budak. Dalam sebuah hadits disebutkan: Dari Ibnu Umar:" Sesungguhnya Nabi telah memeriksa pada salah satu peperangannya. Beliau mendapati seorang perempuan terbunuh. Maka beliau tidak membenarkan membunuh perempuan dan anak-anak" (HR. Bukhari dan Muslim). Kedua, tawanan laki- laki dewasa. Hukuman yang ditimpakan terhadap mereka diserahkan kepada imam atau panglima umum. Keduanya berhak mempertimbangkan mana yang lebih maslahat bagi Islam di antara empat jenis hukuman, yaitu: (a) dihukum berat (mati), (b) dibebaskan, (c) ditukar dengan tawanan musuh (orang Islam yang ditawan musuh, atau dengan harta benda umat Islam yang jatuh ke tangan musuh), atau (d) dijadikan hamba sahaya, jika yang demikian itu dianggap lebih maslahat terhadap Islam. ${ }^{36}$

Muhammad Abu Zahroh berpendapat bahwa bagi tawanan laki-laki dewasa hanya berlaku ketentuan Al Qur'an yang memerintahkan kepada panglima atau penguasa (waliyul $a m n$ ) supaya memilih satu dari dua saja, yaitu meminta tebusan diri mereka, atau dengan segala ramah hati membebaskan mereka. Tebusan ini boleh diganti dengan pertukaran tawanan. Jika tawanan yang bersangkutan miskin, atau untuk kepentingan Islam lebih baik dibebaskan maka sebaiknya mereka segera dibebaskan dengan lemah-lembut dan penuh pemaafan karena dalam hal ini ada nilai da'wah. ${ }^{37}$

Sedikit berbeda dengan Muhammad Abu Zahroh, Muhammad Ali Ashobuny menjelaskan bahwa para fuqaha bersepakat atas bolehnya membunuh tawanan, bahkan Imam Al Jashosh berpendapat bahwa hal ini telah menjadi ijma' dan bersandar pada hadits-hadits mutawatir dan praktik dari rasulullah sendiri. Diantara tawanan yang telah dibunuh antara lain 'Uqbah bin Abi Mu'aith dan Nadhir bin Harits yang dibunuh setelah tertawan dalam perang Badar.

${ }^{34}$ Sulaiman Rasjid, Fiqih Islam, Sinar Baru Algensindo, Bandung, 2001, hlm.462-463

${ }^{35}$ M. Abu Zahroh. Op. Cit., hlm. 150

${ }^{36}$ M. AliAshobuny, Rowaa'i' al Bayaan: Tafsiru Ayaat alAhkam min al Qur'an, Juz II, Maktabah 'Ashriyyah, Beirut, 2003, hlm. 422. Lihat juga Ahkam al Qur'an li Imam al Jashos. Juz. Ill, hlm. 391

${ }^{37}$ Lihat Tatsir Ruhul Ma'anilial Alusi. Juz. XXVI, hlm. 40 
Rosululloh juga memerintahkan untuk membunuh Halal bin Khothol, Abdullah bin Abi Sarh dan Maqis bin Hababah pada waktu Fathul Makah. Rasulullah juga memerintahkan untuk membunuh semua laki-laki dewasa dari bani Quroidhoh berdasarkan keputusan Sa'ad bin Mu'adz, salah seorang sahabat yang juga berasal dari bani Quroidhoh, yang mereka pilih sebagai hakim setelah mereka menghianati perjajian dengan umat Islam di Madinah..$^{38}$

Ketika hendak membunuh tawanan ada beberapa persyaratan yang harus dipenuhi. Al Alusi mengharuskan adanya persetujuan atau perintah dari Imam atau pimpinan tertinggi atau panglima perang. Jadi seorang tentara tidak boleh dengan kehendak dirinya sendiri membunuh tawanan tanpa perintah dari pimpinan tertinggi atau panglima perang. Kemudian jika ia masuk Islam setelah tertawan maka tawanan tersebut boleh dijadikan budak. Sedangkan jika orang tersebut telah masuk Islam sebelum tertangkap maka secara otomatis dia merdeka. ${ }^{39}$

Muhammad Abu Zahroh berpendapat bahwa selain dari dua penyelesaian di atas, yaitu meminta tebusan atau membebaskan tawanan, Islam tidak menentukan yang lain. Bahkan perbudakan yang terjadi di masa lalu bukan merupaka efek dari ajaran Islam. Al Qur'an sendiri tidak memberikan izin untuk memperbudak orang yang merdeka. Nabi sendiri tidak pernah menjadikan seseorang yang merdeka menjadi budak, tetapi malah sebaliknya. ${ }^{40}$

Timbul pertanyaan kenapa terdapat perbudakan dalam Islam dan kenapa terdapat budak-budak di zaman Nabi dan zamam sahabat. Jawabnya adalah tidak terdapat di dalam Al Qur'an suatu ayat atau nashyang melarangnya meskipun Al Quran condong kepada pelarangannya. Maka dalam soal ini terjadilah kebijaksanaan atas dasar perlakuan yang sama. Bila musuh memperbudak tawanan dari kaum muslim, maka tawanan dari pihak merekapun akan dijadikan budak juga oleh umat Islam. Begitu juga sebaliknya, jika musuh tidak memperbudak tawanan dari kaum muslim maka orang-orang Islam dilarang memperbudak tawanan yang mereka miliki. ${ }^{41}$ Dengan demikian, tawanan perang di dalam Islam (figih) diperlakukan dengan śangat manusiawi. Kehormatan dan martabat pribadinya pun juga dijamin dalam penjagaan. Hal ini disebabkan karena pada dasarnya perlakuan yang diberikan kepada mereka harus sejalan dengan prinsip kemaslahatan.

\section{Perbandingan Antara Konsep Perlindung- an Tawanan Perang Menurut Hukum Humaniter Internasional dan Hukum Islam \\ Wahbah Zuhaily menjelaskan bahwa tujuan dari Hukum Islam sebagaimana terangkum dalam maqasid asy syariah al khamsah yaitu:}

${ }^{38}$ M. Abu Zahroh. Op. Cit., hlm. 151

${ }^{39} \mathrm{lbid}$.

${ }^{40}$ Wahbah al Zuhaily, Ushul Al Figh Al Islami, al Thab'ah al Saniyah, al Mathba'ah al 'Ilmiyah, Damsyiq, 1969, him 498. Lihat juga H. Muhammad Hasyim, Konsep Hukum Humaniter Internasional dalam Perspektif Hukum Islam, Makalah disampaikan pada Basic Course International Humanitarian Law and Human Right tanggal 1-5 Maret 2004. di Hotel Barito Banjarmasin, kerja sama Fakultas Syariah IAIN Antasari Banjarmasin dengan ICRC.

${ }^{41}$ Lihat Al Qur'an dan Terjemahnya QS. Al Maidah (5): 32 
(a) Hitz al din: perlindungan terhadap hak dan kewajiban beragama masyarakat, (b) Hifz al nais: perlindungan terhadap kelangsungan hidup manusia, (c) Hitz al aql: perlindungan terhadap potensi kecerdasan jiwa masyarakat, (d) Hifz al nasl: perlindungan terhadap keutuhan ikatan perkawinan guna persambungan yang abadi antar generasi. (e) Hifz al mal: perlindungan terhadap hak-hak kepemilikan. ${ }^{42}$

Nilai-nilai kemanusiaan (al insaniyah) yang terangkum dalam maqasid asy syariah al khamsah (lima dasar tujuan Hukum Islam) yang dipandang sebagai tujuan dan cita-cita universal dalam agama Islam tidak ada satupun yang bertentangan dengan prinsipprinsip dan tujuan Hukum Humaniter Internasional. Bahkan kelima dasar tujuan Hukum Islam tersebut juga merupakan nilainilai humanitarian (al insaniyah) yang juga mendapatkan perlindungan dari sistem hukum manapun. Dari kelima nilai-nilai humanitarian yang juga sekaligus merupakan maqasid asy syariah di atas, yang menjadi titik tekan dalam pengaturan terhadap tawanan perang adalah prinsip hifz an nafs (pemeliharaan jiwa). Baik Hukum Humaniter Internasional maupun Hukum Islam, keduanya memberikaan penghormatan yang tinggi terhadap hak dan kemerdekaan seseorang untuk hidup.

Dengan memahami dan menganalisis ayat-ayat Al Qur'an yang berbicara tentang tawanan dapat diketahui bahwa ternyata nilainilai Islam yang mengatur tentang perlindungan tawanan perang memiliki banyak kesamaan dan sejalan dengan aturan-aturan yang terdapat dalam Hukum Humaniter Internasional, khususnya Konvensi Jenewa III tahun 1949 dan Protokol Tambahan I tahun 1977. Allah berfirman dalam Al Qur'an surat Al Maidah ayat 32:43

Artinya: "Karena itu kami tetapkan bagi Bani Israil, siapapun yang membunuh orang tanpa alasan atau merusak di bumi seolaholah ia membunuh manusia seluruhnya. Dan siapa yang menyelamatkan seseorang seakan-akan ia telah menyelamatkan seluruh manusia..."

Ayat ini menunjukkan bahwa pada dasarnya Islam mengajarkan umatnya untuk menghargai dan menghormati hak hidup seseorang. Penghormatan terhadap hak hidup ini tidak hanya berlaku pada saat damai saja, tetapi dalam kondisi perang pun harus tetap ditegakkan. Allah berfirman dalam surat Al Baqarah ayat 190:44

Artinya: "Dan perangilah di jalan Allah orangorang yang memerangi kamu, (tetapi) janganlah kamu melampaui batas, karena sesungguhnya Allah tidak menyukai orangorang yang melampaui batas."

Ayat ini mengandung maksud bahwa meskipun dalam kondisi perang, umat Islam tidak boleh memperlakukan musuh dan tawanan dengan tidak manusiawi. Penyiksaan maupun pelanggaran terhadap kehormatan sangat tidak sejalan dengan jiwa ayat ini. Yang dimaksud dengan "melampaui batas" dalam ayat ini menurut Imam Ibnu Katsir adalah melakukan halhal yang dilarang, seperti memotong-motong mayat, menjarah, membunuh wanita dan anakanak yang tertawan, menganiaya dan membunuh orang-orang tua yang tertangkap, serta melakukan tindakan-tindakan yang tidak manusiawi terhadap mereka. ${ }^{45}$

${ }^{42}$ Lihat Al Qur'an dan Terjemahnya QS. Al Baqarah (2): 190

${ }^{43}$ Sayyid Quthub, FiZhilaall Qur'an; TafsirdiBawah NaunganAl Qur'an, Juz Kedua, Bina Ilmu, Jakarta, hlm. 160.

${ }^{44}$ Lihat Al Qur'an dan Terjemahnya Q.S. Al Insan (76): 8-9

${ }^{45}$ Lihat Pasal 18 Geneva Conventioan relative to the Treatment of Prisoners of War 1949 
Untuk lebih memperjelas adanya kesesuaian dan persamaan prinsip antara Hukum Humaniter dan Hukum Islam dapat dilihat dalam firman Allah:46

"Dan mereka memberikan makanan yang disukainya kepada orang miskin, anak yatim, dan orang-orang yang di tawan. Sesungguh-nya kami memberikan makanan kepada kamu hanyalah untuk mengharap keridloan Allah, kami tidak menghendaki balasan dari kamudan tidak pula (ucapan) terima kasih."

Ayat ini menerangkan bahwa syari'at Islam mengharuskan umatnya untuk memperlakukan para tawanan dengan baik. Bahkan umat Islam secara implisit diharuskan untuk memberikan persediaan makanan yang cukup dan pantas. Ketentuan ini tentunya memiliki kesesuain dengan ketentuan hukum humaniter terutama Pasal 18 Konvensi Jenewä III tahun 1949 yang menyebutkan bahwa barang-barang untuk keperluan pribadi harus tetap dimiliki tawanan termasuk pakaian dan makanan. ${ }^{47}$ Ketentuan dalam surat Al Insaan ayat 8 dan 9 di atas juga sesuai dengan ketentuan pasal 20 Konvensi Jenewa III tahun 1949 yang menyebutkan bahwa dalam hal evakuasi tawanan harus diselenggarakan dengan perikemanusiaan. Negara/pihak penahan harus memberi makanan dan air yang dapat diminum cukup, serta pakaian dan pemeliharaan kesehatan yang diperlukan serta segala tindakan pencegahan yang wajar untuk menjamin kesehatan selama evakuasi.

Ketentuan tentang perlakuan terhadap tawanan perang dalam Islam pada prinsipnya sejalan dengan Konvensi Jenewa lil 1949 dan Protokol Tambahan I 1977 yang secara garis besar berisi sebagai berikut:48

a) Menjamin penghormatan; artinya para tawanan perang harus diperlakukan secara manusiawi,

b) Menjamin perlindungan; artinya mereka harus dilindungi dari ketidakadilan dan bahaya yang mungkin timbul dari suątı peperangan, dan terhadap kemungkinan atas perkosaan integritas kepribadian mereka. Harus ada tindakan-tindakan yang perlu untuk menjamin hal ini.

c) Memberikan perawatan kesehatan; artinya mereka berhak atas perawatan kesehatan yang setara dan tidak boleh diabaikan, walaupun ia pihak musuh.

Di samping persamaan di atas, nilai-nilai dasar dari Hukum Islam yang mengatur tentang tawanan perang juga memiliki kesamaan dengan prinsip dasar Hukum Humaniter Internasional. Prinsip pengaturan tawanan perang yang tersirat dalam surat Al Baqarah ayat 190 sejalan dengan tiga prinsip dasar dalam Hukum Humaniter Intemasional. Arti dari ayat tersebut adalah: 49

"Dan perangilah di jalan Allah orang-orang

${ }^{46}$ Hans Peter Gasser, International Humanitarian Law, An Introduction, Separate Print from Hans Haug, Humanity for All, International Red Cross and Red Crescent Movement, Henry Dunant Institute, Berne Stuttgart, Paul Haupt Publisher, Vienna, 1993, hlm 29-30

${ }^{47}$ Lihat Terjemahan Q.S. Al Baqarah (2): 190

${ }^{48}$ Lina Hastuti, Arti Penting Penyebarluasan Hukum Humaniter Internasional, Dalam Jurnal Yuridika, Vol. 15, No. 3, Edisi Mei 2000, FH Airlangga, Surabaya, 2000, hlm. 238

${ }^{49} \mathrm{H}$. Muhammad Hasyim, Konsep Hukum Humaniter Intemasional dalam Perspektif Hukum Islam, Makalah disampaikan pada Basic Course International Humanitarian Law and Human Right tanggal 1-5 Maret 2004. di Hotel Barito Banjarmasin, kerja sama Fakultas Syariah IAIN Antasari Banjarmasin dengan ICRC, HIm 7 
yang memerangi kamu, (tetapi) janganlah kamu melampaui batas, karena sesungguhnya Allah tidak menyukai orang-orang yang melampaui batas."

Jika dikaji secara mendalam meialui kitab-kitab tafsir klasik maka akan didapat suatu simpulan bahwa ayat 190 ini senafas dengan prinsip-prinsip Hukum Humaniter Internasional sebagai berikut:50

a. Prinsip Pembatasan (limitation principle) Maksud prinsip ini adalah hak setiap pihak yang terlibat dalam konflikuntuk menentukan senjata yang akan digunakan adalah terbatas, tidak boleh secara sembarangan yang bisa menimbulkan kerusakan yang tidak perlu.

b. Prinsip Proporsionalitas (proporsional principle)

Lina Hastuti menerangkan bahwa maksud dari prinsip ini adalah bahwa jumlah kekuatan dan persenjataan yang digunakan dalam perang haruslah seimbang dengan musuh yang dihadapi sehingga dapat menghindari jatuhnya korban penduduk sipil yang tidak perlu.

r. Prinsin Pembedaan (distinction principle) Inti dari prinsip pembedaan ini adalah adanya pembedaan antara penduduk sipil (civilian) dengan peserta tempur (combatant) dan pembedaan antara objek sipil dengan objek militer. Pembedaan ini sangat diperlukan dalam rangka menghindari korban yang tidak perlu.

Selain persamaan-persamaan tersebut, hukum Humaniter Internasional dan Hukum
Islam secara historis memiliki titik temu. Pirzada sebagaimana dikutip dalam Ensikiopedi Hukum Islam menyatakan adanya keterkaitan yang tidak terpisahkan persambungan dinamika hukum secara internasional. la menjelaskan bahwa al qanun al dualy yang diteladani dari Nabi Muhammad memberikan pengaruh yang sangat besar pada ahli-ahli Hukum Internasional Eropa seperti Pierro Bello, Victoria, dan Alberico Gentili (1552-1608) dalam merumuskan hubungan internasional. Dasar-dasar hubungan internasional ini mereka pelajari dari Spanyol, pusat peradaban Islam abad ke-8 sampai abad ke-15, dan mereka kembangkan di Eropa. Hugo Grotius (1583-1645) sendiri yang dianggap sebagai Bapak Hukum Internasional mengakui besarnya pengaruh Islam dalam penulisan De Jure Belli ac Pacis. ${ }^{5}$ Dengan adanya titik temu antara Hukum Internasional dengan Hukum Islam maka wajar jika Hukum Humaniter Internasional, khususnya yang mengatur tentang tawanan perang, memiliki prinsip dan nilai yang sejalan dan senafas dengan prinsip-prinsip dan nilai-nilai pengaturan tawanan perang dalam Islam.

Di samping beberapa persesuaian dan titiktemu di atas, sebenamya konsep perlindungan tawanan perang dalam Hukum Humaniter Internasional dan Hukum Islam juga memiliki banyak perbedaan. Namun perbedaan yang ada tidak terjadi pada level prinsip dan asas dasar keduanya. Kebanyakan perbedaan terjadi pada hal-hal teknis, seperti masalah penggolongan tawanan, jenis sanksi, kodfifikasi, dan semacamnya. Hal ini terjadi karena Hukum Humaniter

${ }^{50}$ H. Muhammad Hasyim, Op. Cit., hlm 7

${ }^{51}$ H. Muhammad Hasyim, Konsep Hukum Humaniter Intemasional dalam PerspektifHukum /slam, Makalah disampaikan pada Basic Course International Humanitarian Law and Human Right tanggal 1-5 Maret 2004. di Hotel Barito Banjarmasin, kerja sama Fakultas Syariah IAIN Antasari Banjarmasin dengan ICRC, HIm 7 
Internasional telah memberikan pengaturan tentang tawanan secara lebih rinci dan terkodifikasi, Sedangkan pengaturan tawanan perang dalam Hukum Islam bersifat global, abstrak dan memerlukan penafsiran lebih lanjut. Hukum Islam secara khusus tidak menjangkau selengkap Hukum Humaniter Internasional, kecuali pada sisi menentukan prinsip-prinsip serta kaidah-kaidah yang masih bersifat umum (kully). Meskipun demikian, Islam memberikan peluang ijthad dengan membuat kesepakatankesepakatan internal suatu bangsa dan negara, kesepakatan antar negara pada tingkat bilateral, regional multilateral dan atau internasional karena pada asasnya dalam konteks muamalah segala sesuatu hukumnya boleh, kecuali jika ada dalil yang melarang (al ashlu $f i$ al asyya' al ibahah hatta yadullu ad dalil 'ala taahrimih). ${ }^{52}$

\section{Simpulan}

Berdasarkan uraian di atas dapat disimpulkan bahwa, pengaturan terhadap tawanan perang Menurut. Hukum Humaniter Internasional dan Hukum Islam apabila dikomparasikan memiliki persamaan dan titik temu sebagai berikut: Pertama, Ketentuan tentang tawanan perang dalam Hukum Islam sejalan dengan Konvensi Jenewa III 1949 dan Protokol Tambahan I 1977 yang secara garis besar berisi tentang jaminan penghormatan, jaminan perlindungan terhadap tawanan, dan jaminan perawatan kesehatan terhadap tawanan.

Kedua, prinsip pengaturan terhadap tawanan perang dalam Al Qur'an, terutama dalam surat Al Baqarah ayat 190 sejalan dengan tiga prinsip dasar dalam Hukum Humaniter Internasional yaitu; Prinsip pembatasan (limitation principle), prinsip proporsionalitas (proporsional principle), dan prinsip pembedaan (distinction principle). Ketiga, Hukum Humaniter Internasional dan Hukum Islam memiliki titik temu dimana al ganun al dauli yang diteladani dari praktik hubungan antar negar yang dilakukan oleh $\mathrm{Nabi}$ Muhammad dan para sahabat memiliki pengaruh yang sangat besar pada ahli-ahli Hukum Internasional dari Eropa. Pada kenyataannya banyak ahli-ahli Hukum Internasional dari Eropa mempelajari dasar-dasar hubungan internasional dari Spanyol, pusat peradaban Islam abad ke-8 sampai abad ke-15.

Di samping beberapa persesuaian dan titik temu di atas, sebenamya konsep perlindungan tawanan perang dalam Hukum Humaniter Internasional dan Hukum Islam juga memiliki banyak perbedaan. Namun perbedaan yang ada tidak terjadi pada level prinsip dan asas dasar keduanya. Kebanyakan perbedaan terjadi pada hal-hal teknis, seperti masalah penggolongan tawanan, jenis sanksi, kodifikasi, dan semacamnya.

\section{Daftar Pustaka}

Abdul Baqiy. 1990. Al Jihadu Sabiluna. Beirut: Mu'asasatu Ar Risalah

Abu Bakar Jabir Al Jaziriy. 2003. Ensiklopedi Muslim Minhajul Muslim.. Jakarta: Darul Kafah

A) Alusi, Tafsir Ruhul Ma'ani, Juz, XXVI Altaf Gauhar. 1982. Tantangan Islam, Alih Bahasa: Anas Mahyudin, PUSTAKA, Perpustakaan Salman ITB, Bandung. Arlina Permanasari, dkk. 1999. Pengantar Hukum Humaniter. Jakarta: International Commit-

${ }^{52} \mathrm{H}$. Muhammad Hasyim, Op. Cit., hlm 7 
tee of The Red Cross (ICRC).

Farah Malekian. 1994. The Concept of Islamic Interbational Criminal Law; A Comparative Study. Lodon: Kluwer Academic Publishers Group.

Hans Peter Gasser. 1993. International Humanitarian Law, An Introduction. Separate Print from Hans Haug, Humanity for All, International Red Cross and Red Crescent Movement, Henry Dunant Institute, Berne Stuttgart, Vienna: Paul Haupt Publisher.

Haryomataram, 1984. Hukum Humaniter.

Rajawali. Jakarta.

Imam al Jashos, Tafsir Ahkam al Qur'ani. Juz III.

J. G. Starke.1989. Introduction to Intemational

Law. Tenth Edition. Butterwoth.

L. Amin Widodo. 1994. Fiqih Siyasah dalam Hubungan Internasional. Yogyakarta: Tiara Wacana.

Majid Khadduri. 1941. The Law of War and

Peace in Islam. Baltimore, Maryland, London: The Johns Hopkins University Press.

M. Abu Zahrah. 1973. Al 'Alaaqatu ad Dauliyah $f i$ al Islam. Alih Bahasa Muhammad Zein Hasan. Jakarta: Bulan Bintang.

M. Ali Ashobuny. 2003. Rowaa'i' al Bayaan: Tatsiiru Ayaat al Ahkam min al Qur'an. Juz II, , Beirut: Maktabah 'Ashriyyah.

Sulaiman Rasjid. 2001. Fiqih Islam. Bandung:

Sinar Baru Algensindo.

Sayyid Quthub. Fi Zhilaalil Qur'an. Juz II. Wahbah al Zuhaily. 1969. Ushul al Figh al
Islami. Damsyiq: al Mathba'ah al 'Ilmiyah, al Thab'ah al Saniyah.

H. Muhammad Hasyim. 2004. Konsep Hukum Humaniter Internasional dalam Perspektif Hukum Islam, Makalah disampaikan pada Basic Course Intemational Humanitarian Law and Human Right tanggal 1-5 Maret 2004 di Hotel Barito Banjarmasin, kejja sama Fakultas Syariah IAIN Antasari Banjarmasin dengan ICRC.

Lina Hastuti. 2000. Arti Penting Penyebarluasan Hukum Humaniter Internasional. Makalah dalam Jurnal Yuridika. Surabaya: FH Airlangga.

Rina Rusman. 2004. Beberapa Perkembangan Hukum Humaniter Internasional. Makalah disampaikan dalam Kursus Dasar HHI dan HAM untuk Dosen Perguruan Tinggi Negeri dan Swasta yang diselenggarakan di Banjarmasin atas kerja sama antara Fakultas Syari'ah IAINAntasari dan ICRC Delegasi Jakarta. Geneva Convention (III) Relative to the Treatment of Prisoners of War; August 12, 1949.

Protocol Additional to the Geneva Conventions of 12 August 1949, and relating to the Protection of Victims of International Armed Conflicts (Protocol 1) Adopted on 8 June 1977 by the Diplomatic Conference on the Reaffirmation and Development of International Humanitarian Law applicable in Armned Conflictsenxtry into force 7 December 1979, in accordance with Article 95. 